\title{
Digital fuel level indicator in two-wheeler along with distance to zero indicator
}

\author{
A.Avinashkumar ${ }^{1}$, U.Singaravelan ${ }^{2}$, T.V.Premkumar ${ }^{3}$, K.Gnanaprakash $^{4}$

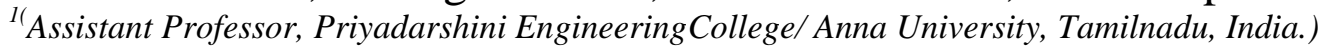 \\ 2, 3,4 (Finalyear Mechanical Engineering, Priyadarshini Engineering College/Anna University, Tamilnadu, \\ India.)
}

\begin{abstract}
Today in this digitized world, if the fuel indicator in the automobiles is also made digital it will help to know the exact amount of fuel available in the fuel tank. The above furnished fact is considered in our project and we found out a proper solution for indicating the exact availability of fuel in the tank digitally. Here, we are indicating the amount of fuel in the tank in litres. This value in litres will be in numerical digits (ex:1.2, 1.3, 1.4). This project mainly concentrates about the indication of fuel level in two- wheeler tanks. Various other features like the distance can be travelled to the corresponding fuel, is added with this arrangement which will explain the clear performance of the vehicle to the corresponding fuel.
\end{abstract}

Keywords :A/D Converter, Analog fuel gauge, Mileage, Two-wheeler.

\section{INTRODUCTION}

The analog fuel gauge has two main units, namely the sending unit and the gauge. Here, when the fuel tank is full, resistance values decreases, current value increases and when the tank is empty, resistance values increases and current value decreases ${ }^{[1]}$. The rear side of the analog fuel gauge has three terminals, namely B-battery, F-float, G-ground. From these terminals, voltage values are taken from the terminals-FG and resistance value is taken from the terminal-F from zero to 11 litres. So, for a particular volt value, the corresponding litres value will be shown in digital ${ }^{[2]}$. Along with this, fuel mileage is also displayed in A/D Convertor to the corresponding fuel in the fuel tank. Fuel mileage in vehicles refers to the relationship between the distances can be travelled by an automobile to the amount of fuel in the fuel tank ${ }^{[3]}$.

\section{PROPOSED SOLUTION}

This project focuses on creating a device which can help to actively display the exact amount of fuel and fuel mileage ${ }^{[4]}$ of a motorbike in real time. It involves the making of the system to provide a mileage indicator which is reliable, easy to read and of dependable/compatible overall design. The system comprises of Fuel tank, Analog fuel gauge, Battery, A/D Converter ${ }^{[5]}$ with LCD display ${ }^{[6]}$.

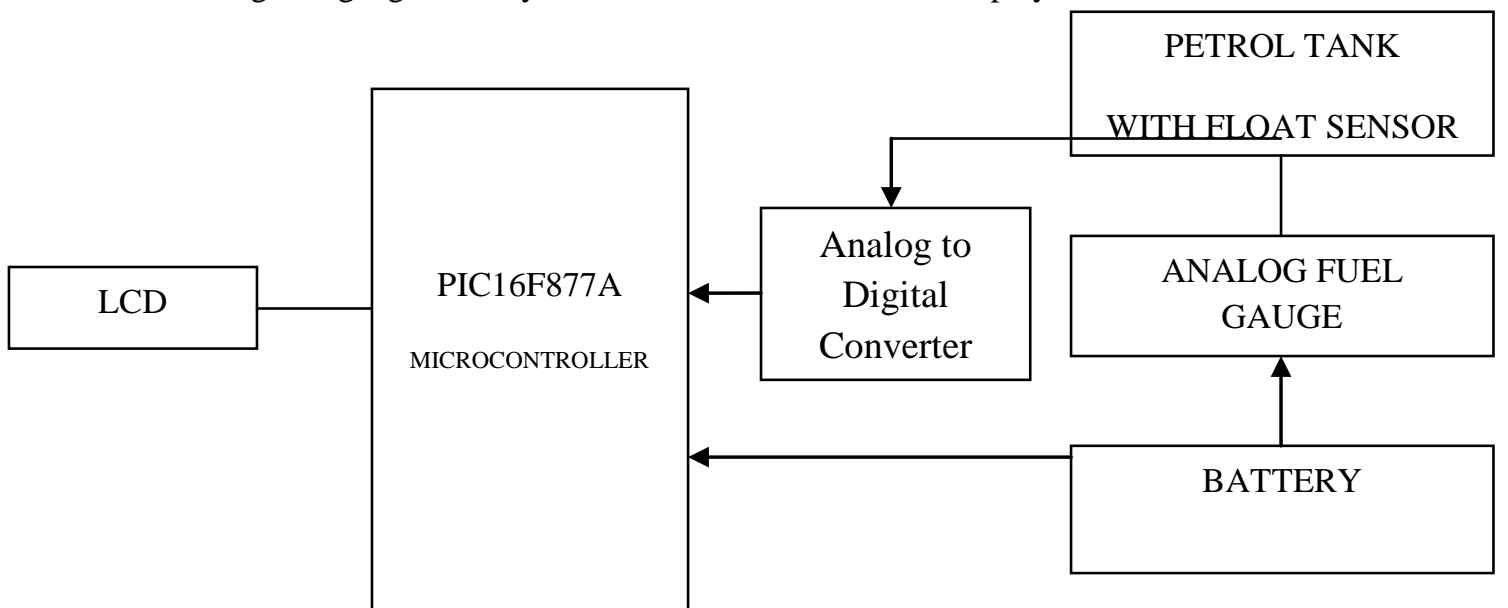

Pic 16F877A Microcontroller

\section{COMPONENTS}

It is an 14-bit words microcontroller and has $8 \mathrm{~KB}$ of Flash programmable and erasable read only memory. It has an operating frequency of DC-20Mhz. 
$L C D$

LCD (Liquid Crystal Display) screen is an electronic display module and finds a wide range of applications. A 16x2 LCD display is very basic module and is very commonly used in various devices and circuits. These modules are preferred over seven segments.

\section{Analog fuel gauge}

It is a device which shows the amount of petrol in petrol tank .(EMPTY , HALF , FULL ).

It is used in most of the two-wheelers.

\section{Petrol Tank with Float}

It is used to store petrol in two-wheelers. Float is an object which sinks over the petrol inside the petrol tank to measure the amount of petrol left in the tank.

\section{A/D Converter}

It is a device which converts analog value into digital value.

Battery

A 12 volt 7Ah battery is used to give supply to Analog fuel gauge, A/D converter along with LCD.

\section{EXPERIMENTATION METHOD}

The rear side of the analog fuel gauge ${ }^{[7]}$ has three terminals, namely F, G and B. From these terminals, we had taken terminals-FG as constant and collected the voltage values from those terminals to the corresponding litres in the petrol tank. By removing the terminal-F separately from the setup, we had taken resistance values from that terminal, to the corresponding litres in the petrol tank. The volt and resistance values was taken with the help of multi-meter. The current is obtained by using the formula, I = V/R.

Rear view of analog fuel gauge connected with multi meter to measure potentials at different fuel levels of tank as in figure

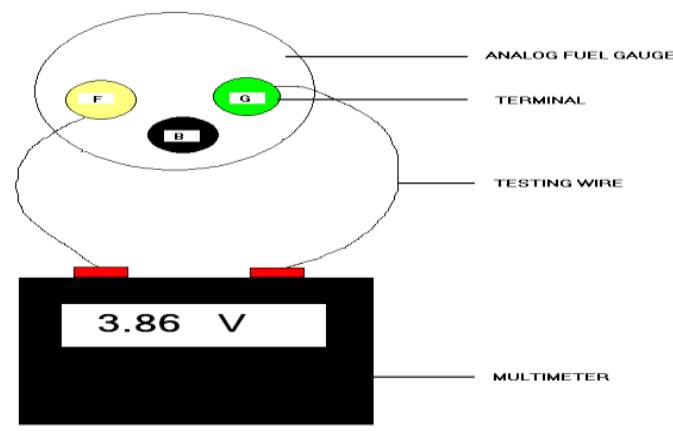

$$
\begin{aligned}
& \text { F - Float } \\
& \text { G - Ground } \\
& \text { B - Battery }
\end{aligned}
$$

\section{Mileage obtained at various speed intervals}

Here the mileage value is taken for 1 litre of petrol and the distance travelled ${ }^{[8]}$ corresponding to it is tabulated below at various speed intervals.

\begin{tabular}{|c|c|c|}
\hline SPEED & \multicolumn{2}{|c|}{ MILEAGE OBTAINED (km/lt) } \\
\hline $\mathbf{( k m} / \mathbf{h r})$ & $\begin{array}{c}\text { SINGLE PERSON } \\
\text { LOAD }\end{array}$ & $\begin{array}{c}\text { DOUBLE PERSON } \\
\text { LOAD }\end{array}$ \\
\hline 10 & 51 & 48 \\
\hline 20 & 54 & 51 \\
\hline 30 & 56 & 53 \\
\hline 40 & 60 & 57 \\
\hline 50 & 58 & 55 \\
\hline 60 & 56 & 53 \\
\hline 70 & 50 & 46 \\
\hline 80 & 44 & 41 \\
\hline 90 & 28 & 25 \\
\hline
\end{tabular}

So, the average mileage for both single person and double person load will be around $\mathbf{5 0}(\mathbf{k m} / \mathbf{l t r})$. 


\section{Description}

In our project the main blocks are micro controller unit, fuel level sensor and LCD display unit. The fuel level detection circuit is used to detect the level of the fuel in the tank; here sensors are placed at certain place to find out the fuel level and the signal is sent to the micro controller unit for further operations.

Here sensor is placed at fuel tank to sense the fuel level and the signal from that sensor is sent to the micro controller unit to decide the exact level ${ }^{[9]}$ information. When the fuel level reaches the top level sensor which means that the tank is full and this will be indicated to the user by means of maximum tank level and the level information is indicated through LCD.

The LCD connected with vehicle which showing the present fuel level as 2.1 litres and the distance can be travelled as 105 Kilometer.

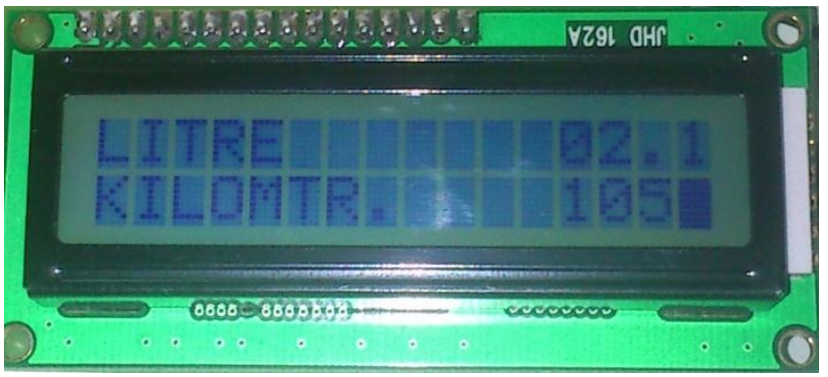

Most of the basic display unit will indicate empty, half, full with analog display ${ }^{[9]}$ but the market available digital display units were displays the information in terms of percentage but our proposed method will displayed in terms of exact fuel level and these information are preprogrammed according to the sensor positional values(Resistance-Voltage). The proposed technique can be improved by adding a buzzer to announce the user about the abnormal conditions like low level, half level and full levels of the fuel tank.

In this project a float type sensor is placed within the fuel tank the variation of the fuel can change the position of variable resistance which is connected with the float. The varied resistance can change the voltage of the analog fuel level indicator to show the approximate value. But the variable resistance from the fuel tank is connected with the analog to digital converter unit to show the exact quantity of fuel in the fuel tank. The setup can show the exact value of fuel in the connected LCD and the setup is programmed to show the distance to zero by considering the rough mileage as $50 \mathrm{kmpl}$. The distance to zero can also be an accurate by programming the microcontroller by taking the input of present mileage with respective speeds and tank levels.

Voltage, Resistance, Current and Distance to zero for various fuel levels is tabulated below,

\begin{tabular}{|c|c|c|c|c|c|c|}
\hline \multirow{2}{*}{$\begin{array}{l}\text { UEL I } \\
\text { FUEL } \\
\text { TANK } \\
\text { (litres }\end{array}$} & \multicolumn{2}{|c|}{ TERMINAL-F } & \multirow{2}{*}{$\begin{array}{c}\text { DIGITS } \\
\text { C CONSID } \\
\text { ( Volts ) }\end{array}$} & \multirow{2}{*}{$\begin{array}{c}\text { ESISTANC } \\
\text { VALUES } \\
\text { IN } \\
(\text { ohms })\end{array}$} & \multirow{2}{*}{$\begin{array}{c}\text { CURREN' } \\
\text { OBTAINE } \\
(\text { amps ) }\end{array}$} & \multirow{2}{*}{$\begin{array}{c}\text { DISTANC } \\
\text { TO ZERC } \\
(\mathrm{KM})\end{array}$} \\
\hline & $\begin{array}{r}\text { MIN } \\
\text { (volts }\end{array}$ & $\begin{array}{c}\text { MAX } \\
\text { (volts) }\end{array}$ & & & & \\
\hline$<1.0$ & 3.82 & 4.00 & 3.83 to 3.82 & $<89.5$ & $<0.0425$ & $<50$ \\
\hline 1.0 & 3.81 & 4.00 & 3.81 & 89.5 & 0.0425 & 50 \\
\hline 1.1 & 3.79 & 4.00 & 3.80 to 3.79 & 88.26 & 0.0430 & 55 \\
\hline 1.2 & 3.77 & 4.00 & 3.78 to 3.71 & 87.02 & 0.0434 & 60 \\
\hline 1.3 & 3.75 & 4.00 & 3.76 to $3.7 \mathrm{~s}$ & 85.78 & 0.0438 & 65 \\
\hline 1.4 & 3.73 & 4.00 & 3.74 to 3.73 & 84.54 & 0.0442 & 70 \\
\hline 1.5 & 3.71 & 4.00 & 3.72 to 3.71 & 83.3 & 0.0446 & 75 \\
\hline 1.6 & 3.69 & 4.00 & 3.70 to 3.68 & 82.06 & 0.0450 & 80 \\
\hline 1.7 & 3.67 & 4.00 & 3.68 to 3.67 & 80.82 & 0.0455 & 85 \\
\hline 1.8 & 3.65 & 4.00 & 3.66 to 3.65 & 79.58 & 0.0459 & 90 \\
\hline 1.9 & 3.63 & 4.00 & 3.64 to 3.63 & 78.34 & 0.0464 & 95 \\
\hline 2.0 & 3.61 & 4.00 & 3.62 to 3.61 & 77.1 & 0.0469 & 100 \\
\hline 2.1 & 3.59 & 4.00 & 3.60 to 3.59 & 75.97 & 0.0473 & 105 \\
\hline 2.2 & 3.57 & 4.00 & 3.58 to 3.57 & 74.84 & 0.0478 & 110 \\
\hline 2.3 & 3.55 & 4.00 & 3.56 to 3.5 & 73.71 & 0.0482 & 115 \\
\hline 2.4 & 3.53 & 4.00 & 3.54 to 3.53 & 72.58 & 0.0487 & 120 \\
\hline 2.5 & 3.51 & 4.00 & 3.52 to 3.51 & 71.45 & 0.0492 & 125 \\
\hline 2.6 & 3.49 & 4.00 & 3.50 to $3.4 \mathrm{~d}$ & 70.32 & 0.0497 & 130 \\
\hline 2.7 & 3.47 & 4.00 & 3.48 to 3.47 & 69.19 & 0.0502 & 135 \\
\hline 2.8 & 3.45 & 4.00 & 3.46 to 3.45 & 68.06 & 0.0508 & 140 \\
\hline
\end{tabular}

\begin{tabular}{|c|c|c|c|c|c|c|}
\hline \multicolumn{3}{|c|}{ UEL ITERMINAL-F } & DIGITS & ESISTAN & CURREN & ISTANO \\
\hline $\begin{array}{l}\text { FUEL } \\
\text { TANK } \\
\text { (litres) }\end{array}$ & $\begin{array}{c}\text { MIN } \\
\text { (volts ) }\end{array}$ & $\begin{array}{c}\text { MAX } \\
\text { (volts) }\end{array}$ & ( Volts ) & (ohms ) & $\begin{array}{c}\text { (amps ) } \\
\text { (anANE }\end{array}$ & $\begin{array}{c}\text { TO ZER } \\
(\mathrm{KM})\end{array}$ \\
\hline 6.0 & 2.81 & 4.00 & $\begin{array}{l}\text { ( } 2.82 \text { to } \\
2.81)\end{array}$ & 38.5 & 0.0732 & 300 \\
\hline 6.1 & 2.79 & 4.00 & $\begin{array}{l}\text { ( } 2.80 \text { to } \\
2.79 \text { ) }\end{array}$ & 37.8 & 0.0740 & 305 \\
\hline 6.2 & 2.77 & 4.00 & $\begin{array}{l}(2.78 \text { to } \\
2.77)\end{array}$ & 37.1 & 0.0749 & 310 \\
\hline 6.3 & 2.75 & 4.00 & $\begin{array}{l}\text { ( } 2.76 \text { to } \\
2.75)\end{array}$ & 36.4 & 0.0758 & 315 \\
\hline 6.4 & 2.73 & 4.00 & $\begin{array}{l}\text { ( } 2.74 \text { to } \\
2.73)\end{array}$ & 35.7 & 0.0767 & 320 \\
\hline 6.5 & 2.71 & 4.00 & $\begin{array}{l}\text { ( } 2.72 \text { to } \\
2.71)\end{array}$ & 35 & 0.0777 & 325 \\
\hline 6.6 & 2.69 & 4.00 & $\begin{array}{l}\text { ( } 2.70 \text { to } \\
2.69)\end{array}$ & 34.3 & 0.0787 & 330 \\
\hline 6.7 & 2.67 & 4.00 & $\begin{array}{l}\text { ( } 2.68 \text { to } \\
2.67) \\
\end{array}$ & 33.6 & 0.0797 & 335 \\
\hline 6.8 & 2.65 & 4.00 & $\begin{array}{l}\text { ( } 2.66 \text { to } \\
2.65)\end{array}$ & 32.9 & 0.0808 & 340 \\
\hline 6.9 & 2.63 & 4.00 & $\begin{array}{l}\text { ( } 2.64 \text { to } \\
2.63) \\
\end{array}$ & 32.2 & 0.0819 & 345 \\
\hline 7.0 & 2.61 & 4.00 & $\begin{array}{l}\text { ( } 2.62 \text { to } \\
2.61)\end{array}$ & 31.5 & 0.0831 & 350 \\
\hline 7.1 & 2.59 & 4.00 & $\begin{array}{l}(2.60 \text { to } \\
2.59)\end{array}$ & 30.91 & 0.0841 & 355 \\
\hline
\end{tabular}


Digital fuel level indicator in two-wheeler along with distance to zero indicator

\begin{tabular}{|c|c|c|c|c|c|c|}
\hline 2.9 & 3.43 & 4.00 & 3.44 to 3.43 & 66.93 & 0.0513 & 145 \\
\hline 3.0 & 3.41 & 4.00 & 3.42 to 3.41 & 65.8 & 0.0519 & 150 \\
\hline 3.1 & 3.39 & 4.00 & 3.40 to 3.39 & 64.78 & 0.0524 & 155 \\
\hline 3.2 & 3.37 & 4.00 & 3.38 to 3.37 & 63.76 & 0.0530 & 160 \\
\hline 3.3 & 3.35 & 4.00 & 3.36 to 3.35 & 62.74 & 0.0535 & 165 \\
\hline 3.4 & 3.33 & 4.00 & 3.34 to 3.33 & 61.72 & 0.0541 & 170 \\
\hline 3.5 & 3.31 & 4.00 & 3.32 to 3.31 & 60.7 & 0.0546 & 175 \\
\hline 3.6 & 3.29 & 4.00 & 3.30 to 3.29 & 59.68 & 0.0552 & 180 \\
\hline 3.7 & 3.27 & 4.00 & 3.28 to 3.27 & 58.66 & 0.0559 & 185 \\
\hline 3.8 & 3.25 & 4.00 & 3.26 to 3.25 & 57.64 & 0.0565 & 190 \\
\hline 3.9 & 3.23 & 4.00 & 3.24 to 3.23 & 56.62 & 0.0572 & 195 \\
\hline 4.0 & 3.21 & 4.00 & 3.22 to 3.21 & 55.6 & 0.0579 & 200 \\
\hline 4.1 & 3.19 & 4.00 & 3.20 to 3.19 & 54.69 & 0.0585 & 205 \\
\hline 4.2 & 3.17 & 4.00 & 3.18 to 3.17 & 53.78 & 0.0591 & 210 \\
\hline 4.3 & 3.15 & 4.00 & 3.16 to 3.15 & 52.87 & 0.0597 & 215 \\
\hline 4.4 & 3.13 & 4.00 & 3.14 to 3.13 & 51.96 & 0.0604 & 220 \\
\hline 4.5 & 3.11 & 4.00 & 3.12 to 3.11 & 51.05 & 0.0611 & 225 \\
\hline 4.6 & 3.09 & 4.00 & 3.10 to $3.0 \mathrm{~s}$ & 50.14 & 0.0618 & 230 \\
\hline 4.7 & 3.07 & 4.00 & 3.08 to 3.07 & 49.23 & 0.0625 & 235 \\
\hline 4.8 & 3.05 & 4.00 & 3.06 to 3.05 & 48.32 & 0.0633 & 240 \\
\hline 4.9 & 3.03 & 4.00 & 3.04 to 3.03 & 47.41 & 0.0641 & 245 \\
\hline 5.0 & 3.01 & 4.00 & 3.02 to 3.01 & 46.5 & 0.0649 & 250 \\
\hline 5.1 & 2.99 & 4.00 & \begin{tabular}{|l|} 
(3.00 to \\
$2.99)$
\end{tabular} & 45.7 & 0.0656 & 255 \\
\hline 5.2 & 2.97 & 4.00 & $\begin{array}{l}\text { ( } 2.98 \text { to } \\
2.97)\end{array}$ & 44.9 & 0.0663 & 260 \\
\hline 5.3 & 2.95 & 4.00 & $\begin{array}{l}(2.96 \text { to } \\
2.95)\end{array}$ & 44.1 & 0.0671 & 265 \\
\hline 5.4 & 2.93 & 4.00 & $\begin{array}{l}(2.94 \text { to } \\
2.93)\end{array}$ & 43.3 & 0.0678 & 270 \\
\hline 5.5 & 2.91 & 4.00 & $\begin{array}{l}\text { ( } 2.92 \text { to } \\
2.91)\end{array}$ & 42.5 & 0.0687 & 275 \\
\hline 5.6 & 2.89 & 4.00 & $\begin{array}{l}\text { ( } 2.90 \text { to } \\
2.89) \\
\end{array}$ & 41.7 & 0.0695 & 280 \\
\hline 5.7 & 2.87 & 4.00 & $\begin{array}{l}(2.88 \text { to } \\
2.87)\end{array}$ & 40.9 & 0.0704 & 285 \\
\hline 5.8 & 2.85 & 4.00 & $\begin{array}{l}\text { ( } 2.86 \text { to } \\
2.85) \\
\end{array}$ & 40.1 & 0.0713 & 290 \\
\hline 5.9 & 2.83 & 4.00 & $\begin{array}{l}2.84 \text { to } \\
2.83)\end{array}$ & 39.3 & 0.0722 & 295 \\
\hline
\end{tabular}

\begin{tabular}{|c|c|c|c|c|c|c|}
\hline 7.2 & 2.57 & 4.00 & $\begin{array}{l}\text { ( } 2.58 \text { to } \\
2.57)\end{array}$ & 30.32 & 0.0850 & 360 \\
\hline 7.3 & 2.55 & 4.00 & $\begin{array}{c}(2.56 \text { to } \\
2.55)\end{array}$ & 29.73 & 0.0861 & 365 \\
\hline 7.4 & 2.53 & 4.00 & $\begin{array}{c}(2.54 \text { to } \\
2.53) \\
\end{array}$ & 29.14 & 0.0871 & 370 \\
\hline 7.5 & 2.51 & 4.00 & $\begin{array}{l}\text { ( } 2.52 \text { to } \\
2.51)\end{array}$ & 28.55 & 0.0882 & 375 \\
\hline 7.6 & 2.49 & 4.00 & $\begin{array}{l}\text { ( } 2.50 \text { to } \\
2.49)\end{array}$ & 27.96 & 0.0894 & 380 \\
\hline 7.7 & 2.47 & 4.00 & $\begin{array}{l}\text { ( } 2.48 \text { to } \\
2.47)\end{array}$ & 27.37 & 0.0906 & 385 \\
\hline 7.8 & 2.45 & 4.00 & $\begin{array}{c}(2.46 \text { to } \\
2.45) \\
\end{array}$ & 26.78 & 0.0918 & 390 \\
\hline 7.9 & 2.43 & 4.00 & $\begin{array}{l}\text { ( } 2.44 \text { to } \\
2.43)\end{array}$ & 26.19 & 0.0931 & 395 \\
\hline 8.0 & 2.41 & 4.00 & $\begin{array}{l}\text { ( } 2.42 \text { to } \\
2.41) \\
\end{array}$ & 25.6 & 0.0945 & 400 \\
\hline 8.1 & 2.39 & 4.00 & $\begin{array}{c}(2.40 \text { to } \\
2.39)\end{array}$ & 25.12 & 0.0955 & 405 \\
\hline 8.2 & 2.37 & 4.00 & $\begin{array}{l}\text { ( } 2.38 \text { to } \\
2.37)\end{array}$ & 24.64 & 0.0965 & 410 \\
\hline 8.3 & 2.35 & 4.00 & $\begin{array}{c}(2.36 \text { to } \\
2.35) \\
\end{array}$ & 24.16 & 0.0976 & 415 \\
\hline 8.4 & 2.33 & 4.00 & $\begin{array}{l}\text { ( } 2.34 \text { to } \\
2.33)\end{array}$ & 23.68 & 0.0988 & 420 \\
\hline 8.5 & 2.31 & 4.00 & $\begin{array}{c}\text { ( } 2.32 \text { to } \\
2.31) \\
\end{array}$ & 23.2 & 0.1 & 425 \\
\hline 8.6 & 2.29 & 4.00 & $\begin{array}{l}(2.30 \text { to } \\
2.29)\end{array}$ & 22.72 & 0.1012 & 430 \\
\hline 8.7 & 2.27 & 4.00 & $\begin{array}{c}(2.28 \text { to } \\
2.27) \\
\end{array}$ & 22.24 & 0.1025 & 435 \\
\hline 8.8 & 2.25 & 4.00 & $\begin{array}{c}(2.26 \text { to } \\
2.25)\end{array}$ & 21.76 & 0.1038 & 440 \\
\hline 8.9 & 2.23 & 4.00 & $\begin{array}{l}\text { ( } 2.24 \text { to } \\
2.23)\end{array}$ & 21.28 & 0.1052 & 445 \\
\hline 9.0 & 2.21 & 4.00 & $\begin{array}{l}\text { ( } 2.22 \text { to } \\
2.21)\end{array}$ & 20.8 & 0.1067 & 450 \\
\hline 9.1 & 2.19 & 4.00 & $\begin{array}{l}\text { ( } 2.20 \text { to } \\
2.19) \\
\end{array}$ & 20.43 & 0.1076 & 455 \\
\hline 9.2 & 2.17 & 4.00 & $\begin{array}{l}\text { ( } 2.18 \text { to } \\
2.17)\end{array}$ & 20.06 & 0.1086 & 460 \\
\hline 9.3 & 2.15 & 4.00 & $\begin{array}{c}(2.16 \text { to } \\
2.15)\end{array}$ & 19.69 & 0.1097 & 465 \\
\hline 9.4 & 2.13 & 4.00 & $\begin{array}{c}\text { ( } 2.14 \text { to } \\
2.13)\end{array}$ & 19.32 & 0.1107 & 470 \\
\hline 9.5 & 2.11 & 4.00 & $\begin{array}{c}(2.12 \text { to } \\
2.11) \\
\end{array}$ & 18.95 & 0.1118 & 475 \\
\hline 9.6 & 2.09 & 4.00 & $\begin{array}{c}(2.10 \text { to } \\
2.09)\end{array}$ & 18.58 & 0.1130 & 480 \\
\hline 9.7 & 2.07 & 4.00 & $\begin{array}{c}(2.08 \text { to } \\
2.07)\end{array}$ & 18.21 & 0.1142 & 485 \\
\hline 9.8 & 2.05 & 4.00 & $\begin{array}{l}\text { ( } 2.06 \text { to } \\
2.05)\end{array}$ & 17.84 & 0.1154 & 490 \\
\hline 9.9 & 2.03 & 4.00 & $\begin{array}{l}\text { ( } 2.04 \text { to } \\
2.03)\end{array}$ & 17.47 & 0.1167 & 495 \\
\hline 10.0 & 2.01 & 4.00 & $\begin{array}{c}(2.02 \text { to } \\
2.01) \\
\end{array}$ & 17.1 & 0.1181 & 500 \\
\hline 10.1 & 1.99 & 4.00 & $\begin{array}{c}\text { ( } 2.00 \text { to } \\
1.99) \\
\end{array}$ & 16.84 & 0.1187 & 505 \\
\hline 10.2 & 1.97 & 4.00 & $\begin{array}{c}(1.98 \text { to } \\
1.97) \\
\end{array}$ & 16.58 & 0.1194 & 510 \\
\hline 10.3 & 1.95 & 4.00 & $\begin{array}{l}\text { ( } 1.96 \text { to } \\
1.95)\end{array}$ & 16.32 & 0.1200 & 515 \\
\hline 10.4 & 1.93 & 4.00 & $\begin{array}{c}(1.94 \text { to } \\
1.93) \\
\end{array}$ & 16.06 & 0.1207 & 520 \\
\hline 10.5 & 1.91 & 4.00 & $\begin{array}{l}\text { ( } 1.92 \text { to } \\
1.91) \\
\end{array}$ & 15.8 & 0.1215 & 525 \\
\hline 10.6 & 1.89 & 4.00 & $\begin{array}{l}\text { ( } 1.90 \text { to } \\
1.89) \\
\end{array}$ & 15.54 & 0.1222 & 530 \\
\hline 10.7 & 1.87 & 4.00 & $\begin{array}{l}\text { ( } 1.88 \text { to } \\
1.87) \\
\end{array}$ & 15.28 & 0.1230 & 535 \\
\hline
\end{tabular}




\begin{tabular}{|l|l|l|l|l|l|l|}
\hline 10.8 & 1.85 & 4.00 & $\begin{array}{c}(1.86 \text { to } \\
1.85)\end{array}$ & 15.02 & 0.1238 & 540 \\
\hline 10.9 & 1.83 & 4.00 & $\begin{array}{c}(1.84 \text { to } \\
1.83)\end{array}$ & 14.76 & 0.1246 & 545 \\
\hline 11.0 & 1.81 & 4.00 & $\begin{array}{c}(1.82 \\
\text { to } \\
\text { below } \\
1.82)\end{array}$ & 14.5 & 0.1255 & 550 \\
\hline
\end{tabular}

\section{CONCLUSION}

The A/D converter with LCD was fitted with the Analog fuel gauge of the two-wheeler and the result was successfully obtained. The A/D converter shows the amount of fuel in fuel tank in exact litres (EX : 1.3, $1.4,1.5)$. The A/D converter shows the exact fuel in litres only when the the fuel in the fuel tank is more then 1 litre. The accuracy level is upto95 $-98 \%$ because the error was around \pm 0.2 litres, because the fuel in the fuel tank was measured on the basis of float level in the tank and we didn't use any other sensors. It displays the exact litres on plane roads and shows error value on slope surfaces.

\section{Future Enhancements}

In future the proposed technique can be improved by adding fuel cells at different places of fuel tank to measure exact fuel levels at different conditions like day/night for particular densities at different altitude conditions of vehicle and a buzzer to announce the user about the abnormal conditions like low level, half level and full levels of the fuel tank to refill or warn themselves. The accurate distance to zero can also be done by programming the microcontroller by taking the input of present mileage with respective speeds and tank levels.

\section{REFERENCES}

[1] Jaimon Chacko Varghese, Binesh Ellupurayil Balachandran "Low Cost Intelligent Real Time Fuel Mileage Indicator for Motorbikes" (IITTEE), Volume-2, Issue-5, April 2013

[2] Deep Gupta, Brajesh Kr. Singh and Kuldeep Panwar "A Prototyping Model for Fuel Level Detector and Optimizer" page no 226 229 - African Journal of Basic \& Applied Sciences 4 (6): 226-229, 2012 ISSN 2079-2034

[3] Daniel R. McGlynn, "Vehicle Usage Monitoring And Recording System", US Patent 4072850, February 1978.

[4] S. Kawamura, :Development of Navigation Control," Toyota Technology, Vol. 34, December 1984.

[5] Ti-Ho Wanga, Ming-Chih Lua and Chen-Chien Hsu, 2009. "Liquid-level measurement using a single digital camera", Elsevier, Measurement, 42(4): 604-610

[6] Farrell G. Butler, “Gasoline Mileage Indicator System,” US Patent 3958453, May 1976

[7] Betta, G., A. Pietrosanto and A. Scaglione,” 1996. A digital liquid level transducer based on opticalfiber”, IEEE Trans. Instrum. Meas., 45: 551-555.

[8] Nitin Jade, Pranjal Shrimali, Asvin Patel, Sagar Gupta “Modified Type Intelligent Digital Fuel Indicator System" IOSR Journal of Mechanical and Civil Engineering (IOSR-JMCE) e-ISSN: 2278-1684, p-ISSN: 2320-334X PP 20-23 in International Conference on Advances in Engineering \& Technology - 2014 (ICAET-2014)

[9] http://www.speedyjim.net

[10] http://www.wisegeek.com/what-is-a-fuel-gauge.htm.

[11] http://www.classictiger.com/mustang/OilPressureGauge.htm 